\title{
POLICY IMPLEMENTATION OF THE EASTERN PARTNERSHIP IN GEORGIA*
}

\author{
Nino Paresashvili, Avtandil Abashishvili \\ Faculty of Economics and Business, \\ Ivane Javakhishvili Tbilisi State University University Street \#2 \\ doi:10.13165/VPA-13-12-4-09
}

Abstract. The present article reflects integration process between Georgia and EU. In particular, the article contains a brief review over the main agreements, which have been concluded between Georgia and EU. Special attention is drawn to the essence of Eastern partnership and its future results. The institutional aspects of neughbourhood policy of Europe and the Eastern partnership have been compared. At the end of the article, considerations concerning future outlook of new bilateral relations are presented.

Keywords: European neughbourhood policy, Eastern partnership, Agreement on Deep and Comprehensive Free Trade, energetic security.

Raktažodžiai: Europos kaimynystès politika, Rytu partnerystè, Susitarimas dèl tvirtos ir visapusiškos laisvosios prekybos, energetinio saugumo.

\section{Introduction}

The relationship between EU and Georgia started in 1992, immediately after the collapse of the Soviet Union, when the independence of Georgia had been reinstated. The EU was the first to support Georgia in hardships in the transition period. In 1995, in Tbilisi the European Commission opened its Representation Office (Delegation). Relations between the EU and Georgia became more intensive, following the Rose Revolution in 2003, when the EU once again confirmed its support to the current economic and social reforms in Georgia.

* This article is part of the electronic conference: „Public Administration in Central Europe: In Search of Tradition“ organized by the Institute of Public Administration at Mykolas Romeris University (Vilnius, Lithuania) in partnership with the Academic Association of Management and Administration (Lithuania) on November 6th and 7th, 2013. 
The EU is a second contributor to Georgia after the USA. During the years 19922004, through various programs the EU allocated to Georgia 420 million Euro (TACIS, ECHO, the FOOD Security Program, EIDHR) [13, p. 55]. It should be noted that during Russian aggression and occupation of Georgian territories in 2008, the Euro Commission implemented rehabilitation programs for conflict regions, which are interrupted nowadays [1, p. 26].

\section{The European Neighbourhood Policy}

On June 14, 2004, Georgia was accepted to the Neighbourhood Policy of Europe. After almost 11 years of negotiations, on November 14, 2006, in Brussels the text of References of the Board on Approval of the EU-Georgia Action Plan was signed.

The Neighbourhood Policy aims to support the process to close political, economic and cultural interrelationships between the EU and neighbour states, and through these means the EU promotes the spread of democracy, stability and welfare around its borders. The Europe Neighbourhood Policy in Georgia has been functioning since June, 2004 (after the Rose Revolution was held in Georgia). The EU offers to its neighbours privileged relations based on democracy, protection of human rights and the rule of Law. This supersedes the frames of a simple cooperation and implies important economic integration and close political interrelationships. The European Neighbourhood Policy does not represent the foreign policy of the EU and its extension policy. It is actually a composition of instruments of the EU Internal policy and extension practice. The European Neighbourhood Policy is a kind of philosophic search, which should response to the question how it may help neighbors while transforming process for introduction of European standards.

In the framework of the Neighbourhood Policy between the EU and Georgia, the fiveyear action plan was agreed, which came into force on November 14, 2006. The Action Plan consists of rather political documents, in which criteria on evaluation of agreed taken obligations and their fulfillment are reflected. With the Action Plan, Georgia takes obligations to accomplish democratic reforms, which implies a more important profile and deep political cooperation on economic integration with the EU. The European Neighbourhood Policy Action Plan is a renewable document. According to development of the relationships between the EU and Georgia and considering the quality and rates of implemented reforms, it is possible to make changes in it. The Office of the State Minister together with Ministries and entities prepares annual plans for implementation of European Neighbourhood Policy Action Plan in the issues for integration in European and EuroAtlantic structures in a format of logical framework (matrix).[6, p. 2].

Despite the mentioned objectives, the Neighbourhood Policy has not been formed as a strong mechanism in order to achieve the objective stated by the EU - retention of stability and peace through the spread of democracy in Europe, including settlement of conflicts. First of all, the mechanism has turned to be rather extended in time, which for regions such as Georgia represented a large problematic issue. It was commonly acknowledged that the implementation of democratic changes did not depend only on good will of the 
local government or opportunity. In foreign threats and conflicts, in which Georgia was involved, the third power permanently interfered. Such circumstances owing interests of the EU required not only activation of democratic institutes from the EU, but also balancing of the mentioned external threats.

In the Neighbourhood Policy, clear criteria for evaluation of reforms implemented by partner-states were not included, also. Furthermore, certain benefits, which should have followed after reforms implemented in a frame of the Neighbourhood Policy, were not seen. The mentioned setback conditioned the transformation of the instrument of the EU Neighbourhood Policy into one of the most important frames of implementation desirable reforms for the region state, while the EU had an excellent opportunity to transform this instrument into the perfect power accelerating reforms.

Part of the problem was also the fact that the Neighbourhood Policy as a regional instrument did not appropriately reflect ambitions of those states, which desired more comprehensive and swift relationships with the EU [1, p. 34].

It should be noted that on May 24, 2011 Katrin Eshton, the Supreme Representative of the EU in the field of foreign and security policy and the Euro Commission, approved the new document on the Neighbourhood Policy of Europe, which embraces more spheres of the society and is supported by additional stimulation system, in order to promote acceleration of the process of the reforms duration. Ms. Katrin Eshton declared: "The EU takes more responsibility towards its neighbours in order to promote democratic changes and economic welfare in these states."

A new Neighborhood Policy of Europe will rely on six main clauses:

1. Support in achieving the high level of democracy. This embraces free and fair election environment, inculcation of supremacy of the law and fundamental freedom. To achieve this goal, a special role of the civil society will be emphasized;

2. Extension of cooperation in political and security issues. Its aim is to review the role of inclusion of the EU in the process of the conflicts settlement and promotion to sustainable economic and social development;

3. "Partnership for mobility". It relates to support that represents the comprehensive framework for the EU member-states and its partners and involves elaboration of measures to eradicate illegal migration and simplification of legal migration and the border management.

4. Deepening of Eastern partnership and support to democracy in the limits of partnership. The EU will offer association agreements to its partners, in which the EU will make attempts to support democratic reforms, simplification of visa regimes, and inclusion of the civil society and sector cooperation, as well;

5. Directing additional financial facilities according to priority spheres. It relates to usage of 1,24 billion Euro for finances of new initiatives, such as cooperation with the civil society and deepening the regional economic development [11, p. 10].

The mentioned changes partially rectified the setbacks of the European Neighborhood Policy. The principle of the new Neighborhood Policy became the high level of democracy, joined responsibility, positive conventionality and differentiation, in other words, the principle of "More for More". 


\section{"Eastern Partnership" - a New Stage of Partnership between the EU and Georgia}

Conception of Eastern partners was created by joint efforts of Poland and Sweden. It aims at deepening of cooperation between the EU and six partner-states (Ukraine, Belorussia, Moldova, Georgia, Armenia, Azerbaijan).

Its first presentation took place in May, 2008 at Minesterial of the EU Council, and after a month it was reviewed by the EU. The official party of Eastern Partnership took place on May 7, 2009 at Prague summit.

The mainstream task of the Eastern Partnership is support to democratic and economic transformation processes in the states of Eastern Europe. Radoslav Sikorsky, Minister of foreign affairs of Poland, explains it in the following way: "The states which are based on liberal-democratic political system and current market economy are the most attractive partners for the EU" [14].

Initiation of the Eastern Partnership has its premises on a general level. Experts shape up new geographic vicinity and current reforms in partner-states, though a more detailed analysis shows that this initiative and, correspondingly, its acceleration are based upon a number of factors, which, according to priorities, may be broken into several groups $[3, \mathrm{p}$. 82]:

- Russian military aggression against Georgia and Russia's and Ukraine's fighting for the reason of gas;

- New geographic vicinity.

\section{The Essence of the Eastern Partnership}

The Euro-Commission initiative concerning Eastern Europe is a new stage towards deepening of neighborhood relations. As it was noted, the initiative embraces Eastern neighborhood states of the Euro-Commission - Azerbaijan, Georgia, Armenia, Ukraine, Moldova and Belorussia.

In Prague summit, which happened in 2009, the Declaration of Eastern Europe was adopted and it was approved as "Eastern Partnership" [9, p. 6]. The partnership relies upon several dedication principles [11]:

- Supremacy of Law;

- Good management;

- Protection of human rights;

- Respect and protection of minorities;

- Market economy;

- Sustainable development.

Generally, the EU offers to their partners political association and more close integration to the EU Economics. The initiative implies a lot of opportunities, including simplified traveling to Europe, increased financial aid within process of reforms, support 
in wide-range institutional construction, settlement in settlement of economic and social inequality, etc. [3, p. 88].

Undoubtedly, following the essential insight into the Eastern Partnership, the question arises why it is necessary to elaborate such format and what is the difference with the Neighborhood Policy, which can be answered in the following ways:

1. The Eastern Partnership gives better and more precise geographic focus and is free from such pantamorphia that features the Neighborhood Policy.

2. New opportunities offered by the Eastern Partnership are more specific, more practical and exemplary than general proposals of the Neighborhood Policy.

3. The Eastern Partnership has higher profile of individual approach than the Neighborhood Policy.

4. Eastern partner presents a very detailed action plan for cooperation.

For a more specific review, the Eastern Partnership offers to member-states the innovations, which are not included in the European Neighborhood Policy at all, which are the following [12]:

- Association Agreement, which with the aim of economic integration embraces the Agreement on Deep and Comprehensive Trade with Europe (DCFTA);

- Pacts on Mobility and Security, which implies simplification of visa regime and cooperation with the EU in combat corruption, organized crime and illegal migration;

- Comprehensive institution building (aiming to support good governance);

- Promotion to Energetic security (either in member-state or in the territory of the EU) by financing infrastructure sphere and by other ways;

- Intensive cooperation in the issues connected with protection of environment and climate;

- Deepening contacts between people;

- Promotion of cooperation between public civil organizations and the government in partner-states and increase of their inclusion in solution of the mentioned problems.

The Eastern Partnership has two working formats of cooperation: bilateral and multilateral.

Bilateral format stipulates deepening and convergence of relations between the EU and partner-states that covers various aspects of relationships. These include the Association Agreement, the DCFTA, visa liberalization, safe environment, convergence of economic and social policy with the EU, strengthening power security. Also, in the framework of bilateral relations, Comprehensive Institution-Building-CIB Programs have been elaborated, which serve to the development of partner-states institutional opportunities in order to proceed reforms.

Multi-format creates a new structure of share in cooperation with best practices in the limits of multi-lateral relations. According to the aims and values of the Eastern Partnership, Cooperation Platforms have been created, which are broken in the following groups:

- Platform 1: democracy, efficient governance and stability; 
- Platform 2: economic integration and convergence with the EU policy;

- Platform 3: protection of environment, change of the climate and energeticsecurity;

- Platform 4: contacts between people.

Each platform has elaborated its own aims and, correspondingly, working programs that serve efficient implementation of the Eatern Partnership Program. Within the limits of multi-lateral relations aiming at the promotion of the thematic platforms, panels have been planned. The panels define the narrowest and specified ways for implementation of cooperation, events, programs, training (e.g., programs, training, etc.). For their elaboration, experts will be invited [12].

\section{The Financial Aspect of the Eastern Partnership}

An individual approach is reflected in the financial aspect of the partnership. In the Prague Declaration, it is noted that the financial aid will be directed towards the achievement of the Eastern Partnership aims and it will also envisage the progress of individual partners [9]. Aside from the grant allocated from the Commonwealth and cofinancing on the national level, the EU will also try to attract additional financing from the side of other contributors, international financial organizations and private sectors. In order to support the implementation of the projects, the Commonwealth will promote deepening of cooperation of the state and the private sectors and, furthermore, summons the Europe Investment Bank and various contributing organizations to help partner-states in the current modernization process and to elaborate the applicable investment project [3, p. 90].

In 2008, the complete annual financing for six Eastern Partners was 450 million Euro and within the Program of the Eastern Partnership for the years 2010-2013, 600 million Euro were allocated, which are attributed to the funds of the Neighborhood Policy and the partnership.

According to the document of the Euro-Commission, the amounts allocated within the limits of the Eastern Partnership will be spent for the following aims:

- Multi-lateral programs for the institutional building (approx. 175 million Euro);

- The pilot programs of regional development, which are destined for the issues on economic and social inequality of regions (approx. 75 million Euro);

- Implementation of Multi-Lateral Trends of Partnership (approx. 350 million Euro).

What regards Georgia, within the limits of the initiative of the Eastern Partnership, the finances allocated for Georgia have increased significantly. In 2007-2010, Georgia received 120 million Euro from the European Neighborhood Policy, in 2011-2013 this amount increased by $50 \%$ and achieved 180 million Euro. The whole financing will be applied to four priority spheres, in the limits of which will be promoted the program of multi-lateral relationships between the EU and Georgia [11, p. 21]. 


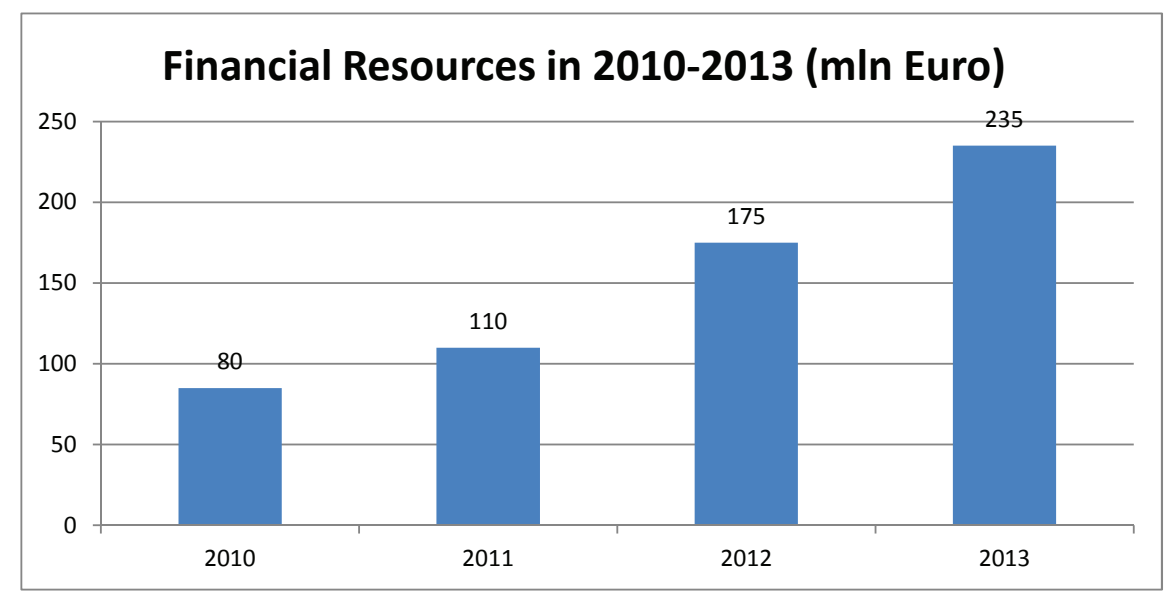

Source: European Commission. Vandemecum on Financing in the Frame of the Eastern Partnership. Brusells, 2010.

Certainly, the amount allotted within the limits of the Eastern Partnership will not in full cover expenditures connected with the reforms to be implemented in Georgia. If political and economic benefits following after the integration of Georgia into the European space are taken into consideration, all critical arguments set out for the last period concerning insignificance of finances from the Eastern Partnership become negligible.

\section{New Bilateral Relations: Economic Integration and Energetic Security}

Within the limits of the Eastern Partnership, the EU offers to partners the political association of higher profile and more activation of ties in main spheres. Based on bilateral talks with the partners, the EU is ready to agree with partners Association Agreements (AAs), which is the main component of the Eastern Partnership initiative. It will replace the Agreement on Partnership and Cooperation with partner-states (PCA), which has been valid till the current period. The content of the Agreement will be different in accordance with tasks and opportunities of the partners. Implementation of the Association Agreement will be promoted by the documents containing the action plans of the European Neighborhood Policy currently in force, in which the aims to be achieved will be reflected in accordance of stages and which will serve as a basis for a program for the reforms to be implemented in a specific state. The bilateral cooperation within the Eastern Partnership between the EU and the partner-state will be developed with the following trends: 1) Arrangement and approval of the Deep and Comprehensive Free Trade Agreement (DCFTA); 2) migration and security; 3) energetic security; 4) support to economic and social development [11].

Besides Georgia, negotiations on the issues for the Association Agreement have started in Armenia and Azerbaijan. 
In contrast to other agreements, the negotiations on the arrangement of the Association Agreement were proceeded without previous preparation period (with exception of a few consultation meetings). From July 15, 2010 till December, 2012, approximately 60 video conferences and 12 plenary sessions were held.

The main part of the Association Agreement has been agreed. Presumably, the talks will be completed after 3-4 rounds, which implies that they should be finished until Vilnius summit, which is planned to happen in 2013. Though, it should be noted that the completion of negotiations on the issue of the Association Agreement does not envisage signing this arrangement, which is also a long process. The Action Plan elaborated within the Neighborhood Policy will come into force before the approval of the Association Agreement. Furthermore, it should be noted that after the completion of the talks on the Association Agreement, the focus will be drawn mainly to institutional consolidation, which will be responsible for the fulfillment of this Agreement [8].

Next, a review, on what context will be developed during the bilateral talks between the EU and partner-states, is presented.

\section{The Agreement on Deep and Comprehensive Free Trade (DCFTA)}

The perspective of the Agreement on Deep and Comprehensive Trade gave new impetus to spheres connected with trade reforms. It should be noted that the DCFTA is one of the components of the Association Agreement. Correspondingly, the Association Agreement cannot be signed without completed negotiations on DCFTA.

In order to start talks about signing the Agreement on Deep and Comprehensive Trade, Georgia should fulfill all obligations, which are taken within the Action Plan of the Neighborhood Policy.

In connection with the fulfillment of necessary conditions, in order to start talks, four comparative problematic spheres from 10 trends (tariff and non-tariff barriers, sanitary and phyto-sanitary measures, state sales, customs administration, investments and service, certificate of origin, withdrawal of technical barriers from trade, competition policy, protection of intellectual issues, sustainable development, environment, social issues) were set out:

- Technical barriers for trade;

- Sanitary and phyto-sanitary control;

- The right of intellectual property;

- Competitive policy.

Concerning all four spheres, the EU presented the package of references to Georgia, in which there is a specific description how the reforms should be conducted and in which way the mentioned spheres will be in harmony with the EU.

In May, 2012, the Parliament of Georgia adopted two Laws, which regulate harmlessness of products and customers right. According to the evaluation of the Eurasia Foundation, their several references were reflected in the last version of the Code. Though, the most part of the proposals, including principal issues, were not taken into consideration. New Codes do 
not create the precondition for the improvement of the situation related to the harmlessness of products and customers rights. Even in some aspects, regress is noted, which estranges Georgia from the EU legislation. It should be noted that Georgia abolished even the old model of food products security (of the Soviet period), though instead of creation of new laws and accomplishment of them (there have been attempts to make legislation, but not its execution mechanism), so far this sector has remained without control, which creates a lot of problems, including export of Georgian products to the EU market.

Significant changes have been made in the Law "On Competition and Free Trade" of April, 2012. However, like the previous reforms, the mentioned reforms do not respond to the main requirements of the EU.

Discussions of the last period concerning the DCFTA and how beneficial it would be for Georgia to fulfill these requirements are not purposeful at the present time. On the one hand, economic studies connected with this issue showed that in a short-term period perspective accomplishment of requirements connected with the DCFTA would cause expenditures for the state administration and for the private sector, as well. On the other hand, within a long-term period perspective, this Agreement would bring large benefits to Georgia [10, p. 131].

\section{Energetic Security}

One of the most important preconditions of the Eastern Partnership is security of power supply and strengthening energetic independence. Even according to the most optimistic calculation, unless the EU transform its energetic policy in a fundamental way and does not make serious investments in this sphere, the EU dependence upon the supplier of energetic power up to the year 2025 will be raised from $50 \%$ ( which is at the present time) to $70 \%$. The dependence of such level on the external supplier creates threats to the political independence of the EU and partner-states. Strengthening energetic security is the main priority of the Eastern Partnership.

The Association Agreements, which should be signed within the limits of the Eastern Partnership, envisage realization of the principle of interdependence between partnerstates in energetic sphere. In energetic context, it implies the opportunity for the partnerstates to involve and to take part in three various policies of the EU, which include the following: the EU trade, the competition policy and the EU power energetic policy. The Eastern Partnership gives the opportunity to Ukraine and Moldova to become competent members of the European energetic Commonwealth. What regards other partner-states Belorussia, Armenia and Azerbaijan - the EU offers the status of supervisor for them (Georgia has this status). The proposal to sign the Memorandum of Understanding with Georgia, Armenia and Moldova is also very important. Cooperation within the limits of the Memorandum covers participation in schemes of power supply and development of energy infrastructure in these states [4]. At the same time, the EU will continue active cooperation with Armenia on the issue of closing Medzamor Nuclear Power Plant. Within the limits of the Eastern Partnership, complete integration of the Ukraine Power Market 
with the EU energy market will take place. Also, the EU-Ukraine cooperation in a sphere of nuclear energetic will be strengthened at Ukrainian nuclear stations. Special attention will be drawn to rehabilitation of the network of Ukraine gas and oil transit.

The document "South Corridor", approved on May 8, YEAR, in the Prague summit, gives a rather specific plan for cooperation in energetic sphere, in which the states of South Caucasia (Georgia, Azerbaijan) play the key role. The Prague Declaration represents a beneficial scheme for all parties coordinated and fair cooperation between customer, producer and transit states.

\section{Conclusion}

The following question remains: will the Eastern Partnership together with the Neighborhood Policy be transformed into a strong tool of peace and stability reforms or not? It can be answered in two ways:

1. First of all, it depends upon the targeted actions of the EU - to help the partnerstates and use opportunities set in this instrument completely.

2. Naturally, further steps depend on the partner-states. At the present time, the EU and Georgia are on the mainstream stage of relationships. The subject of the review is not only power security and signing the Deep and Comprehensive Trade Agreement, but also aspiration of Georgia to start negotiations with the EU on the Association Agreement as soon as possible. This will become an additional and strong tool for democratic development.

\section{References}

1. Akobia, E. European Union and Georgia: Current Issues and Prospects for the Future. Publisher, 2009.

2. Chaillot, P. Pioneering Foreign Policy. October, 2007.

3. Chkoidze, V. European Union and Georgia: Current Issues and Prospects for the Future. Publisher, 2009.

4. Declaration: Prague Summit-Southern Corridor-Ref: CL09-102EN. UE: Council, UN forum, 8/5/2009.

5. Emerson, M., Noutcheva, G., and Popescu, N. European Neighbourhood Policy Two Years on: Time Indeed for an 'ENP plus'. CEPS Policy Brief, March 2007, No 126, 1215.

6. European Commission. European Neighborhood Policy, EU/Georgia Action Plan. 2006.

7. European Commission. European Neighborhood Policy Strategy Paper. Brussels, 2004.

8. European Security Strategy. A Secure in a Better World. Brussels, 12 December, 2003.

9. Council of the European Union. Joint Declaration of the Prague EaP Summit. Brussels, 2009.

10. Kakulia, M. European Union and Georgia: Current Issues and Prospects for the Future. Publisher, 2009.

11. Khokrishvili, E. Eastern Partnership and Georgian Social-economic Politics. Publisher, 2011.

12. Liberal Academy. Who is Who in Brussels in Georgia and South Caucasus. Publisher, 2012. 
13. Marchetti, A. Consolidation in Times of Crisis? The Setup of the ENP and Its Challenges. In: L. Declora and E. Tulmets (eds.). Pioneer Europe, Testing EU Foreign Policy in the Neighborhood. Baden-Baden, 2007.

14. Sikorski, R. The EU's "Eastern Partnership" with Former Soviet States Holds the Key to Relations with Russia. Europe's World Summer. Publisher, 2009.

Nino Paresashvili, Avtandil Abashishvili

\section{Rytų partnerystès politikos ịgyvendinimas Gruzijoje*}

Anotacija

Straipsnyje aptariami Gruzijos ir ES integracijos procesai. Pirmiausia trumpai apžvelgiami pagrindiniai susitarimai, sudaryti tarp Gruzijos ir ES. Ypatingas dėmesys skiriamas Rytų partnerystei ir jos ateities tikslams. Lyginamas institucinių aspektų neughbourhood politiką Europoje ir Rytų partnerystę. Straipsnis baigiamas pastabomis apie naujų dvišalių santykių perspektyvas.

Nino Paresashvili - Tbilisio valstybinio universiteto docentas, ekonomikos mokslų daktaras. E. paštas: niniparesashvili@mail.ru Avtandil Abashishvili - Sukhishvilio universiteto verslo adminitravimo magistras.

E. paštas: flexstudent2008@gmail.com

Nino Paresashvili, Doctor of Economic Science, Tbilisi State University, Assistant Professor. E-mail: niniparesashvili@mail.ru

Avtandil Abashishvili is the Master of Business Administration at Sukhishvili University.

E-mail: flexstudent2008@gmail.com

Straipsnis įteiktas redakcijai 2013 m. spalio 8 d.; recenzuotas; parengtas spaudai 2013 m. spalio mèn.

* Pranešimas šio straipsnio tema buvo pateiktas elektroninejje konferencijoje „Viešasis administravimas centrinejje Europoje: tradicijos paieškos“, organizuotoje Mykolo Romerio universiteto Viešojo administravimo instituto kartu su Akademine vadybos ir administravimo asociacija (AVADA) 2013 m. lapkričio 6-7 dienomis. 